\title{
Perilaku Harian Monyet Hitam Sulawesi (Macaca nigra) pada Masa Kebuntingan di Cagar Alam Tangkoko-Batuangus, Sulawesi Utara
}

\section{Behavior of Crested Macaque (Macaca nigra) During Pregnancy at Tangkoko-Batuangus Nature Reserve, North Sulawesi}

\author{
ANDRE PASETHA ${ }^{1}$, DYAH PERWITASARI-FARAJALLAH ${ }^{1,2^{*}}$, GHOLIB ${ }^{3}$ \\ 'Departemen Biologi, Fakultas Matematika dan Ilmu Pengetahuan Alam, Institut Pertanian Bogor, \\ Kampus IPB Dramaga, Bogor 16680 \\ ${ }^{2}$ Pusat Studi Satwa Primata, Institut Pertanian Bogor, Bogor 16151 \\ ${ }^{3}$ Fakultas kedokteran hewan, Universitas Syiah Kuala, \\ Banda Aceh 23111
}

Diterima 2 April 2019/Disetujui 12 Juni 2019

\begin{abstract}
Crested macaque (Macaca nigra), one of the seven endemic primates in Sulawesi is the most endangered macaque species that has been categorized as critically endangered by International Union for Conservation of Nature (IUCN). However, almost nothing is known about the reproductive biology in associated with the behavioral during pregnancy. The data is important to support a management and breeding programs such as pregnancy diagnostic and conservation program in this species. The research aimed was to study the behavior of the crested macaques during pregnancy. Observations were performed on the 10 adult females of the group of Rambo 1 (R1) which has been habituated at Tangkoko-Batuangus Nature Reserve, North Sulawesi. Behavioral data were collected using focal animal sampling and recorded using instantanaeous sampling on females during menstrual cycling, pregnancy, and after parturition (lactation). During five months observations, a total of 393.63 observation hours were recorded. The results showed that daily activities of the $\mathrm{M}$. nigra during menstrual cycling were dominated by feeding $(26.60 \%)$, foraging $(\mathbf{1 5 . 9 5 \% )}$, and locomotion $(16.16 \%)$. Daily activities during pregnancy was dominated by feeding $(27.03 \%)$, foraging $(\mathbf{1 6 . 3 7 \%})$, and resting $(13.45 \%)$, whereas after parturition (lactation) period is dominated by resting $(26.12 \%)$, foraging $(\mathbf{1 9 . 5 1 \%})$, and feeding $(14.98 \%)$. The resting was the most activity in the end of pregnancy and few day after parturition. The diets were collected successfully composed of the fruits (34 species), arthropods (3 species, 2 families, 4 orders), fungi (4 genus), and plants ( 5 species). Climate was influenced on the composition of the diet, especially on fruit and arthropods. In conclusion, the activity budgets were different during menstrual cycling, pregnancy, and lactation, especially feeding, foraging, locomotion, and resting.
\end{abstract}

Key words: M. nigra, menstrual cycling, pregnancy, lactation, diet

\section{PENDAHULUAN}

Latar Belakang. Sulawesi merupakan hotspot biodiversitas di Indonesia yang berada dalam zona Wallacea (Whitten 1987). Hal tersebut ditunjukkan dengan adanya tujuh spesies macaca (dari 22 genus Macaca) endemik di Sulawesi (Fooden 1969; Melfi 2010; Sari 2013). Salah satu spesies tersebut yaitu monyet hitam sulawesi (Macaca nigra) atau yaki (nama lokal). M. nigra memiliki status konservasi sangat terancam punah (critically endangered) (IUCN red list 2009). Hal ini wajar mengingat jumlah

*Penulis korespondensi:

E-mail: witafar@yahoo.com populasi M. nigra dari tahun ke tahun terus menurun (Sugardjito et al. 1989). Menurunnya jumlah populasi M. nigra disebabkan oleh hilangnya habitat akibat dari pembangunan dan pertumbuhan populasi manusia yang berkembang cepat serta perburuan liar untuk dimakan dagingnya (O’Brien dan Kinnaird 1997; Rosenbaum et al. 1998; Riley 2010; Palacios 2012; Sari 2013).

Betina monyet hitam sulawesi menunjukkan tanda seksual berupa pembengkakan disekitar area urogenital (swelling) yang mana pembengkakan tersebut meningkat pada fase folikuler dan mencapai ukuran maksimum sekitar waktu ovulasi. Panjang siklus menstruasi berkisar antara 23-45 hari (rata-rata= 33.5 hari), masa subur adalah lima hari sebelum terjadi 
detumescens yaitu terjadinya pengempisan swelling (defleting) (Gholib 2011; Higham et al. 2012). Jika terjadi kebuntingan, maka setelah detumescens betina tidak menunjukkan tanda-tanda akan kembali siklus yaitu tidak mengalami pembengkakan (swelling) kembali. Masa kebuntingan M. nigra berkisar antara 174-190 hari.

Penelitian mengenai $M$. nigra telah banyak dilakukan. Namun, penelitian pada aspek reproduksi khususnya mengenai perilaku harian masih terbatas dan hanya dilakukan di penangkaran (Asteria et al. 2008). Selain itu, $M$. nigra telah dikatergorikan sebagai satwa sangat terancam punah (critically endangered) oleh IUCN (2009) sehingga data yang dihasilkan dapat dijadikan sebagai bahan pendugaan kebuntingan untuk menunjang keberhasilan program pengembangbiakan dan konservasi pada satwa ini.

Perumusan Masalah. Penelitian tentang aspek reproduksi masih terbatas pada penelitian eksperimental. Penelitian pada aspek reproduksi khususnya perilaku harian pada masa kebuntingan pada M. nigra belum pernah dilakukan. Oleh karena itu, data perilaku harian terkait aspek produksi di habitat aslinya sangat diperlukan untuk program konservasi baik ex-situ maupun in-situ.

Tujuan Penelitian. Secara umum penelitian ini bertujuan untuk mengkaji perilaku harian monyet hitam sulawesi (M. nigra) pada masa kebuntingan. Secara khusus penelitian ini bertujuan untuk:

1. Mendapatkan gambaran pola dan proporsi perilaku harian $M$. nigra pada masa kebuntingan.

2. Menganalisis perbedaan proporsi perilaku harian M. nigra pada periode siklus menstruasi, kebuntingan (mester 1, mester 2, dan mester 3) dan setelah melahirkan (laktasi).

3. Menginventarisasi jenis pakan dan membuat proporsi komposisi pakan $M$. nigra.

4. Menganalisis hubungan aspek iklim (suhu dan curah hujan) terhadap komposisi pakan M. nigra.

Manfaat Penelitian. Penelitian ini diharapkan dapat menjadi bahan pendugaan kebuntingan dari sisi perilaku untuk program pengembangbiakan (breeding) dan konservasi baik ex-situ maupun in-situ.

\section{BAHAN DAN METODE}

Waktu dan Tempat. Serangga Penelitian dilaksanakan pada bulan Februari-Juni 2014 di Cagar Alam (CA) Tangkoko-Batuangus, Sulawesi Utara (Gambar 1). Analisis data dilakukan di stasiun penelitian Macaca Nigra Project (MNP).
Materi dan Alat. Materi yang diamati yaitu $M$. nigra betina dari kelompok Rambo 1 (R1) yang telah terhabituasi. Pada penelitian ini diamati sebanyak 10 betina dewasa $M$. nigra dari total individu di kelompok R1 sebanyak 89 individu (Tabel 1).

Alat untuk penelitian meliputi: binokuler, handheld Workabout Pro M, jam tangan, GPS, binokuler, kamera, obrometer, dan termometer maksimum-minimum.

Identifikasi dan Habituasi Individu. Identifikasi individu dilakukan dengan mengamati tanda khusus seperti bekas luka, bentuk dan warna puting, bentuk pantat, dan raut wajah. Proses habituasi bertujuan agar monyet tidak terganggu dengan kehadiran pengamat. Selama pengambilan data, pengamat menggunakan pakaian yang sama seperti yang telah digunakan oleh pengamat sebelumnya.

Pengamatan dan Pencatatan Data Perilaku. Pengamatan perilaku harian menggunakan Focal Animal Sampling, yaitu mengikuti dan mengamati satu individu yang diobservasi dalam durasi waktu tertentu. Pencatatan perilaku harian menggunakan Instantaneous sampling yaitu mencatat perilaku dengan interval setiap satu menit (Martin dan Bateson 1993).

Data perilaku yang dicatat meliputi autogrooming (a), aggressive (ag), feeding (fe), foraging (fo), grooming (g), locomotion (1), out of seen (oos), position/ resting (p), social (s), dan drink (d). Pengamatan dan pencatatan perilaku harian dilakukan mulai pagi hari ketika monyet turun dari pohon tidur sampai naik ke pohon tidur pada sore hari.

Data ditabulasi menggunakan pivot table. Proporsi perilaku harian dikelompokkan dan dihitung berdasarkan perbedaan waktu diurnal: pagi hari (06:0010:00), tengah hari (10:00-14:00), dan petang hari (15:00-18:00) serta pada periode siklus menstruasi,

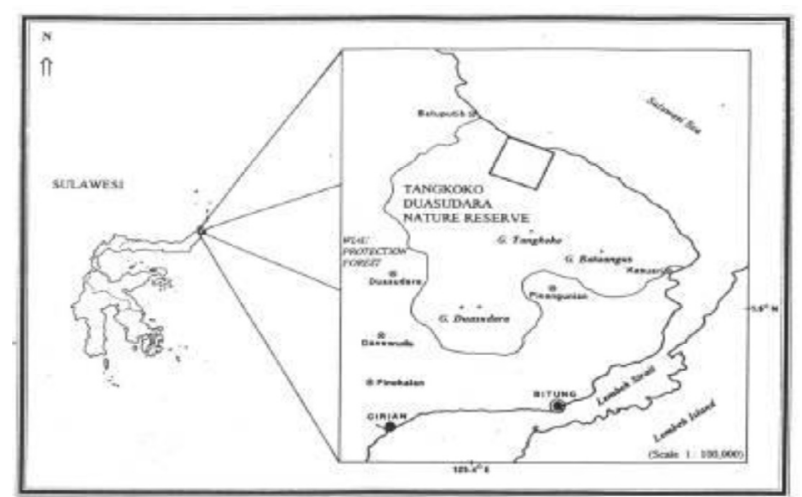

Gambar 1. Peta lokasi penelitian di CA Tangkoko-Batuangus (O’Brien dan Kinnaird 1997)

Tabel 1. Komposisi kelompok R1 berdasarkan perbedaan kelompok umur dan jenis kelamin di CA TangkokoBatuangus

\begin{tabular}{|c|c|c|c|c|}
\hline \multirow{2}{*}{$\begin{array}{l}\text { Grup } \\
\text { rambo 1 } \\
\text { (R1) }\end{array}$} & Dewasa & Remaja & \multirow{2}{*}{ Anakan } & \multirow{2}{*}{ Bayi Total } \\
\hline & Jantan Betina & Jantan Betina & & \\
\hline & 32 & 10 & 25 & 89 \\
\hline
\end{tabular}


kebuntingan (mester 1, mester 2, dan mester 3), dan setelah melahirkan (laktasi).

Pengambilan Gambar Kulit disekitar Daerah Urogenital. Pengambilan gambar kulit disekitar daerah urogenital akan dilakukan dengan menggunakan kamera digital. Setelah gambar kulit disekitar daerah urogenital diambil, diambil juga gambar standar (color card atau color palette) pada tempat, jarak dan kondisi pencahayaan yang sama ketika gambar urogenital diambil.

Inventarisasi dan Identifikasi Pakan. Inventarisasi pakan dilakukan dengan mengamati secara langsung pakan yang dimakan yaitu: buah (f), bunga (fl), artropoda (a), jamur (m), dan tumbuhan (p). Data inventarisasi pakan yang didapatkan kemudian dibuat menjadi data komposisi pakan setiap bulannya. Identifikasi pakan dilakukan dengan menanyakan kepada asisten MNP. Pakan yang belum teridentifikasi dikirim ke LIPI Cibinong, Jawa Barat.

Pencatatan Data Curah Hujan dan Suhu. Suhu dan curah hujan diukur setiap pagi hari. Curah hujan dan suhu diukur menggunakan obrometer dan termometer suhu minimum-maksimum. Data iklim harian selanjutnya dihitung rataan selama satu bulan sehingga menjadi data iklim bulanan.

Analisis Data. Data perilaku harian dianalisis secara deskriptif dan dilanjutkan dengan uji non parametrik menggunakan uji Friedman dan korelasi Pearson. Uji Friedman digunakan untuk menguji perbedaan proporsi perilaku harian berdasarkan perbedaan mester kebuntingan, periode siklus menstruasi, kebuntingan, dan laktasi. Korelasi Pearson digunakan untuk melihat korelasi antara aspek iklim dengan komposisi jenis pakan setiap bulannya.

\section{HASIL}

Perilaku Harian $M$. nigra pada Masa Kebuntingan Berdasarkan Perbedaan Waktu Diurnal. Dari data yang telah dikoleksi dari bulan Februari sampai dengan Juni 2014 diperoleh data perilaku harian sebanyak 393.63 jam. Pagi hari $M$. nigra bunting memiliki proporsi perilaku harian yaitu makan (21.67\%), mencari makan (16.87), lokomosi (15.15), posisi (10.87\%), grooming (10.84\%), autogrooming (6.27\%), agresif (2.01\%), sosial $(1.34 \%)$, dan minum $(0.28 \%)$. Tengah hari M. nigra bunting memiliki proporsi perilaku harian yaitu makan (27.71\%), mencari makan (16.92\%), grooming (13.85\%), posisi (10.53\%), autogrooming $(9.60 \%)$, lokomosi $(6.69 \%)$, sosial $(1.85 \%)$, agresif $(0.54 \%)$, dan minum $(0.07 \%)$. Pada petang hari $M$. nigra bunting memiliki proporsi perilaku harian yaitu makan (21.07\%), mencari makan (15.56\%), lokomosi (11.08\%), posisi (10.33\%), grooming
(8.65\%), autogrooming (8.22\%), sosial $(2.04 \%)$, agresif $(0.24 \%)$, dan minum $(0.22 \%)$.

Proporsi perilaku harian M. nigra betina bunting berdasarkan perbedaan waktu diurnal menunjukkan perbedaan proporsi untuk setiap waktu (Gambar 2).

Perilaku Harian $M$. nigra Berdasarkan Perbedaan Mester Kebuntingan. Panjang masa kebuntingan $M$. nigra kurang lebih enam bulan yang dapat dibagi menjadi tiga mester yaitu: dua bulan pertama (mester 1), dua bulan kedua (mester 2), dan dua bulan ketiga (mester 3). Proporsi perilaku harian $M$. nigra pada tiap mester kebuntingan menunjukkan proporsi yang berbeda (Gambar 3).

Hasil penelitian menunjukkan bahwa perilaku makan pada mester kedua lebih besar $(33.16 \%)$ dibandingkan pada mester pertama (25.21\%) dan ketiga (25.38\%). Namun, hasil uji statistika menunjukkan tidak ada perbedaan antara proporsi perilaku makan pada mester 1 sampai mester 3 kebuntingan $(\mathrm{p}>0.05)$. Proporsi perilaku posisi dan lokomosi pada mester 1 sampai mester $3(10.96 \%$; $14.69 \% ; 13.38 \%)$ dan $(8.49 \% ; 9.12 \% ; 9.82 \%)$. Berdasarkan uji statistika juga tidak ada perbedaan antara proporsi perilaku posisi ( $\mathrm{p}>0.05$ ) dan lokomosi $(\mathrm{p}>0.05)$ pada mester 1 sampai 3 kebuntingan.

Perubahan Intensitas Warna Kulit di Sekitar Daerah Urogenital. Selain data perilaku yang dapat dijadikan bahan untuk menduga individu betina $M$. nigra dalam periode kebuntingan, ada tanda lain yang dapat diamati secara visual yaitu adanya perubahan intensitas warna kulit disekitar daerah urogenital (Gambar 4).

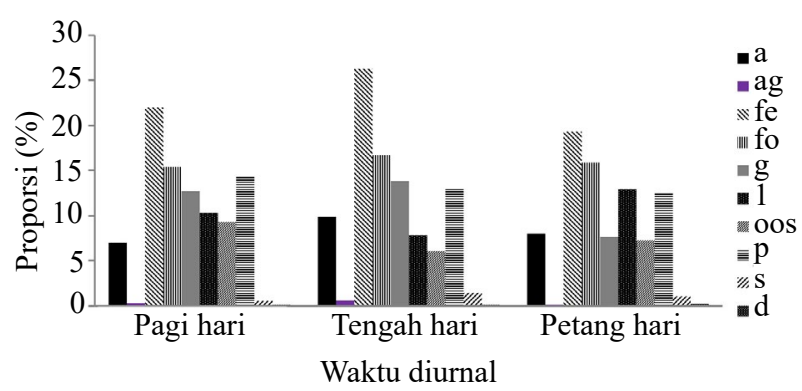

Gambar 2. Proporsi perilaku harian M. nigra pada masa kebuntingan berdasarkan perbedaan waktu diurnal (pagi hari, tengah hari, dan petang hari)

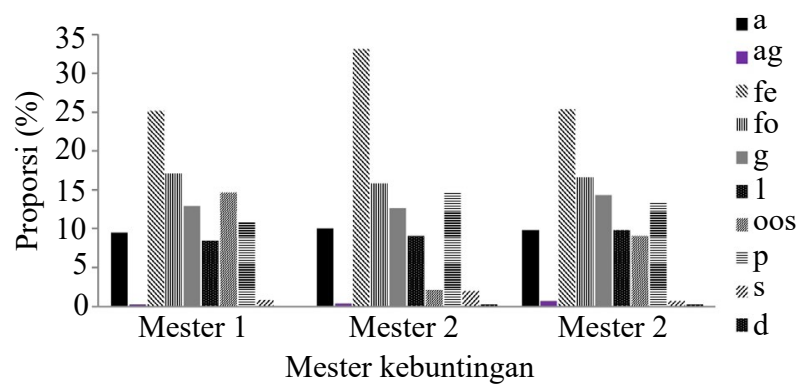

Gambar 3. Perilaku harian M. nigra bunting pada tiga mester kebuntingan 

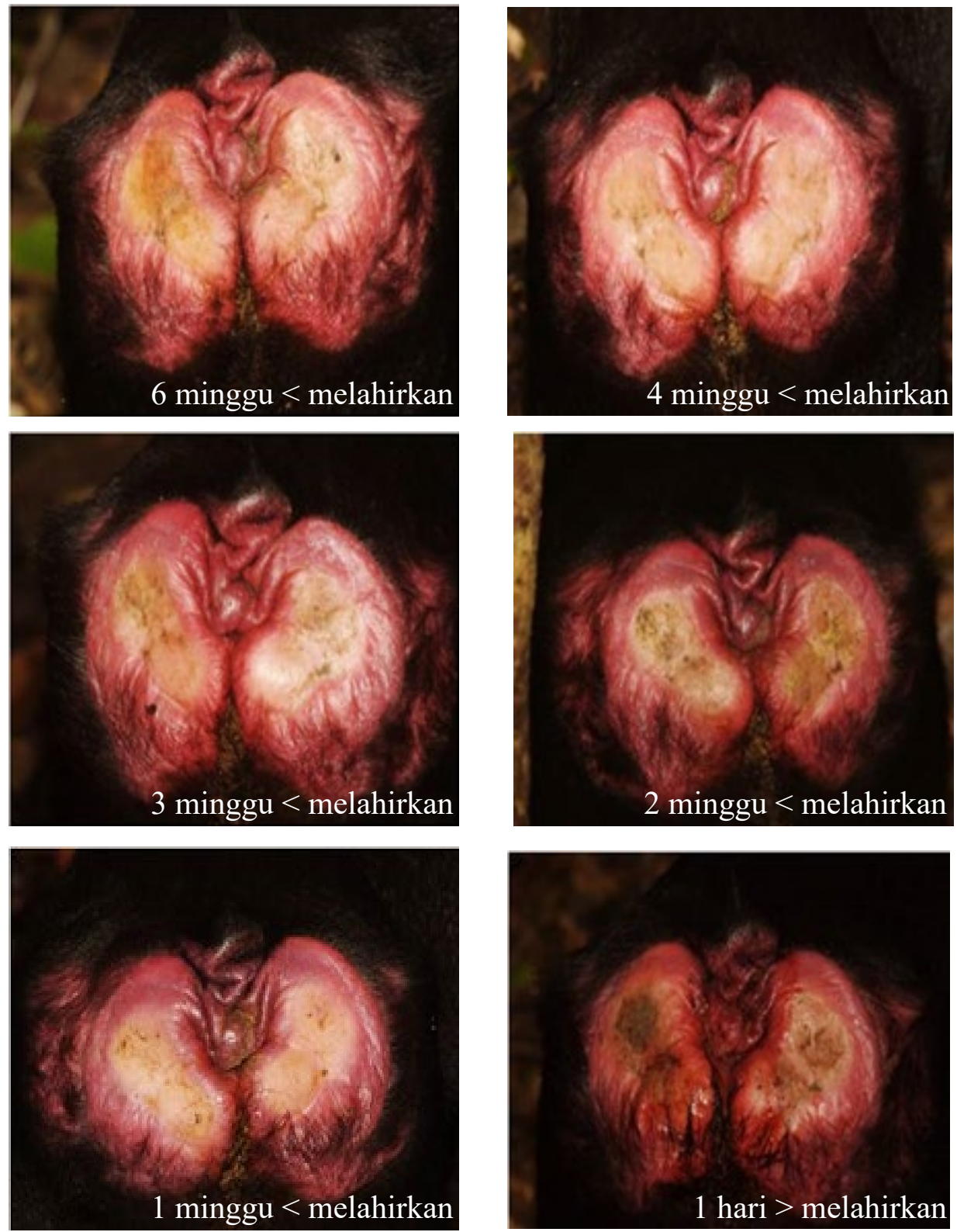

Gambar 4. Perubahan intensitas warna di sekitar daerah urogenital sebelum melahirkan dan laktasi

Betina bunting menunjukkan intensitas warna kulit yang lebih merah dibandingkan betina tidak bunting. Warna kulit pada betina tidak bunting lebih cerah dibandingkan ketika bunting. Intensitas warna kulit tersebut berubah menjadi merah keungu-unguan (magenta) terutama pada periode mendekati waktu melahirkan (beberapa hari sebelum melahirkan).

Perbandingan Perilaku Harian M. nigra pada Periode Siklus Menstruasi, Kebuntingan, dan Laktasi. Perbedaan proporsi perilaku harian $M$. nigra pada periode siklus menstruasi, kebuntingan, dan laktasi (Gambar 5). Perilaku harian pada periode siklus menstruasi didominasi oleh perilaku makan (26.60\%), lokomosi (16.16\%), dan mencari makan (15.95\%). Pada periode kebuntingan perilaku yang mendominasi yaitu perilaku makan (27.03\%), mencari makan (16.37\%), dan posisi (13.45\%). Periode laktasi

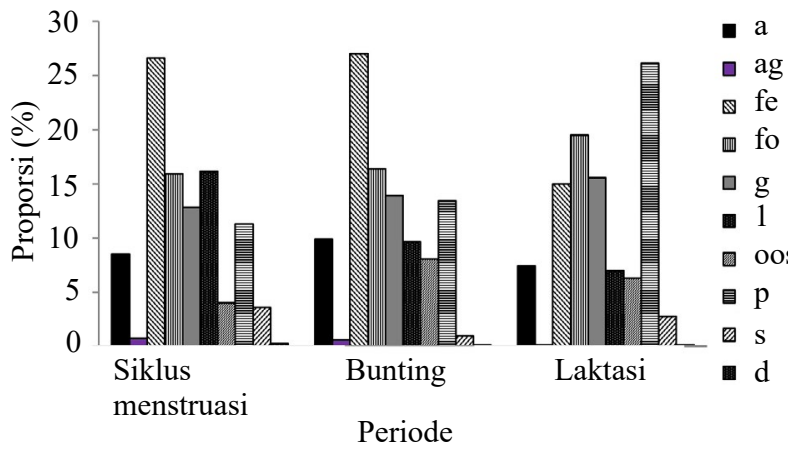

Gambar 5. Perilaku harian M. nigra berdasarkan perbedaan status reproduksi (periode siklus, bunting, dan laktasi)

ditandai dengan tingginya perilaku posisi $(26.12 \%)$ dan rendahnya perilaku lokomosi(7.03\%). Hasil uji statistik menunjukkan adanya perbedaan yang nyata $(\mathrm{p}<0.05)$ dari proporsi perilaku makan dan posisi pada periode 
siklus menstruasi, bunting, dan laktasi sedangkan tidak ada perbedaan untuk perilaku mencari makan dan lokomosi ( $\mathrm{p}>0.05)$.

Inventarisasi Pakan M. nigra di Cagar Alam Tangkoko-Batuangus. Hasil inventarisasi pakan $M$. nigra betina pada masa kebuntingan dapat dilihat pada Tabel 2.

Pakan M. nigra terdiri dari buah (34 spesies), artropoda (3 spesies; 2 famili; 4 ordo), tumbuhan
(5 spesies), dan jamur (4 genus). Dari 34 spesies buah, paling banyak berasal dari famili moraceae dan anacardiaceae (Tabel 2).

Proporsi dan Komposisi Jenis Pakan M. nigra.

Selama lima bulan pengamatan menunjukkan bahwa M. nigra mengkonsumsi artropoda (a), buah (f), jamur (m), tumbuhan (p), dan lainnya (Gambar 6).

Komposisi jenis pakan mengalami fluktuasi setiap bulannya (Gambar 7). Buah menjadijenis pakan tertinggi

Tabel 2. Jenis pakan M. nigra betina selama periode kebuntingan

\begin{tabular}{|c|c|c|c|}
\hline Jenis pakan & Spesies & Famili & Bagian yang dimakan \\
\hline \multirow{40}{*}{ buah (f) } & Macaranga mappa & Euphorbiaceae & buah \\
\hline & Macaranga tanarius & Euphorbiaceae & buah \\
\hline & Morinda citrifolia & Rubiaceae & buah \\
\hline & Morinda bracteata & Rubiaceae & buah \\
\hline & Terminalia catappa & Combrettaceae & kulit luar buah \\
\hline & Dracontomelon dao & Anacardiaceae & buah \\
\hline & Ficus variegata & Moraceae & buah \\
\hline & Garcinia tetranda & Guttiferae & buah \\
\hline & Ficus virens & Moraceae & buah \\
\hline & Arenga pinnata & Arecaceae & buah \\
\hline & Piper aduncum & Piperaceae & buah \\
\hline & Cocos nucifera & Arecaceae & buah \\
\hline & Cananga odorata & Annonaceae & buah \\
\hline & Ixora macrantha & Rubiaceae & buah \\
\hline & Spondias dulcis & Anacardiaceae & buah \\
\hline & Eugenia odorata & Myrtaceae & buah \\
\hline & Ficus microcarpa & Moraceae & buah \\
\hline & Artocarpus dadah & Moraceae & buah \\
\hline & Terminalia celebica & Combrettaceae & kulit luar buah \\
\hline & Dracontomelon & & \\
\hline & mangiferum & Anacardiaceae & buah \\
\hline & Mucuna albertisii & Fabaceae & buah \\
\hline & Euodia minahasae & Rutaceae & buah \\
\hline & Caryota mitis & Arecaceae & buah \\
\hline & Vitex coffasus & Lamiaceae & buah \\
\hline & Passiflora foetida & Passifloraceae & buah \\
\hline & Aglaia odorata & Meliaceae & buah \\
\hline & Leea indica & Vitaceae & buah \\
\hline & Tabernaemontana & & \\
\hline & macrocarpa & Apocynaceae & buah \\
\hline & Koordersiodendron & & \\
\hline & pinnatum & Anacardiaceae & buah \\
\hline & Dendrocnide & & \\
\hline & microstigma & Urticaceae & buah \\
\hline & Polyalthia celebica & Annonaceae & buah \\
\hline & Leea rubra & Vitaceae & buah \\
\hline & Palaquium amboinense & Sapotaceae & buah \\
\hline & Stercularia comosa & Sterculiaceae & buah \\
\hline & Piper aduncum & Piperaceae & daun, batang, tunas \\
\hline & Caryota mitis & Arecaceae & tunas \\
\hline \multirow{8}{*}{$\begin{array}{l}\text { tumbuhan } \\
\text { (p) }\end{array}$} & Leea indica & Vitaceae & daun \\
\hline & Nephrolepsis biffarta & Dryopteridaceae & daun \\
\hline & Barringtonia asiatica & Lecythidaceae & daun muda \\
\hline & Liana & & batang \\
\hline & Anoplolepsis gracilipes & Formicidae & seluruh tubuh \\
\hline & Acropyga sp. & Formicidae & seluruh tubuh \\
\hline & - & Geometridae & seluruh tubuh \\
\hline & - & Geometridae & seluruh tubuh \\
\hline \multirow{6}{*}{$\begin{array}{l}\text { tumbuhan } \\
\text { (p) }\end{array}$} & kumbang & (Ordo:Coleoptera) & seluruh tubuh \\
\hline & Rayap & (Ordo:Isoptera) & seluruh tubuh \\
\hline & Laba-laba & (Ordo:Arachnida) & seluruh tubuh \\
\hline & Ngengat & (Ordo:Lepidoptera) & seluruh tubuh \\
\hline & Telur semut & Formicidae & telur semut \\
\hline & Russula sp. & & tubuh buah \\
\hline \multirow{3}{*}{$\begin{array}{l}\text { tumbuhan } \\
\text { (p) }\end{array}$} & Termitomyces sp. & & tubuh buah \\
\hline & Amanitopsis sp. & & tubuh buah \\
\hline & Pleurotus sp. & & tubuh buah \\
\hline
\end{tabular}


(40-60\%). Komposi buah paling besar terjadi pada bulan Maret (62\%). Pakan dengan proporsi terbesar berikutnya yaitu artropoda (20-40\%). Tumbuhan dan jamur memiliki proporsi $<10 \%$.

Pengaruh Aspek Iklim Terhadap Komposisi Pakan M. nigra. Curah hujan dan suhu menunjukkan sesuatu yang berbanding terbalik. Jika curah hujan tinggi maka suhu rendah. Hal sebaliknya, jika suhu tinggi maka curah hujan rendah. Tinggi dan rendahnya curah hujan dan suhu mempengaruhi komposisi pakan M. nigra setiap bulannya (Gambar 8).

Bulan Februari dan Maret merupakan masa terakhir dari musim hujan. Jika curah hujan tinggi, komposisi pakan berupa buah juga tinggi (61.42\% dan $62.54 \%)$ sedangkan komposisi artropoda rendah $(28.66 \%$ dan 21.57\%). Pada bulan April sampai dengan Mei yang merupakan awal musim kemarau dengan curah hujan yang rendah dan suhu mulai tinggi, komposisi artropoda meningkat $(32.47 \%, 39.28 \%$, dan $44.76 \%)$ sedangkan komposisi buah menurun $(43.50 \%, 51.61 \%$, dan 51.06\%).

Hasil uji statistika menunjukkan hubungan antara curah hujan dan buah memiliki korelasi positif $(r=0.727)$. Hal tersebut mengindikasikan jika curah hujan tinggi maka komposisi buah akan tinggi. Curah hujan dan artropoda memiliki korelasi negatif $(r=$
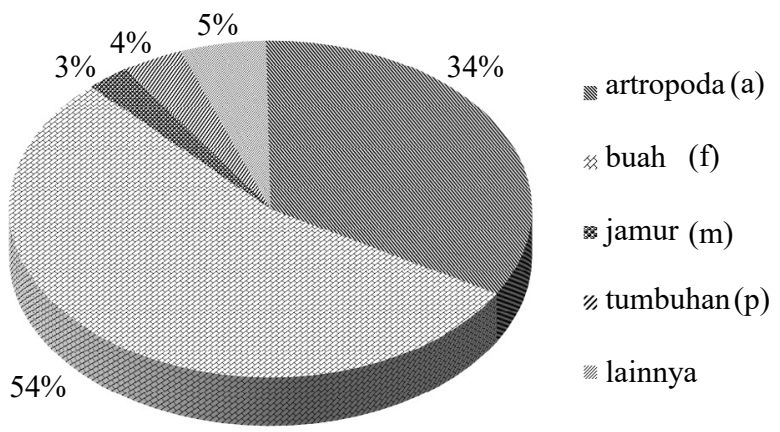

Gambar 6. Proporsi jenis pakan M. nigra selama periode kebuntingan
-0.709) yaitu jika curah hujan tinggi maka komposisi artropoda rendah dan sebaliknya. Hubungan antara suhu dan buah serta suhu dan artropoda menunjukkan korelasi negatif $(r=-0.056)$ dan $(r=-0.580)$, ketika suhu tinggi maka komposisi buah dan artropoda akan rendah dan sebaliknya.

\section{PEMBAHASAN}

Perilaku Harian M. nigra pada Masa Kebuntingan Berdasarkan Perbedaan Waktu Diurnal. Menurut O'Brien dan Kinnaird (1997) primata terestrial dan semi arboreal seperti $M$. nigra biasa menunjukkan suatu siklus diurnal dari perilaku hariannya. M. nigra merupakan hewan yang aktif pada siang hari (Giyarto 2010). Waktu aktif tersebut digunakan oleh $M$. nigra dalam proporsi yang berbedabeda (O’Brien dan Kinnaird 1997). Dari tiga kategori
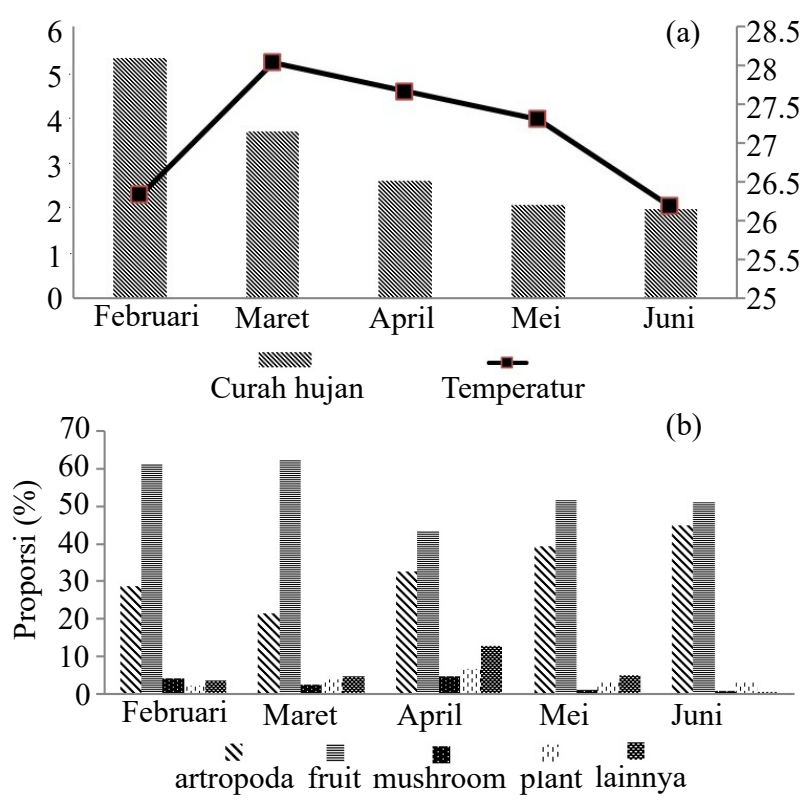

Gambar 8. (a) Curah hujan dan suhu, (b) Komposisi pakan $M$. nigra per bulan Februari sampai dengan Juni 2014

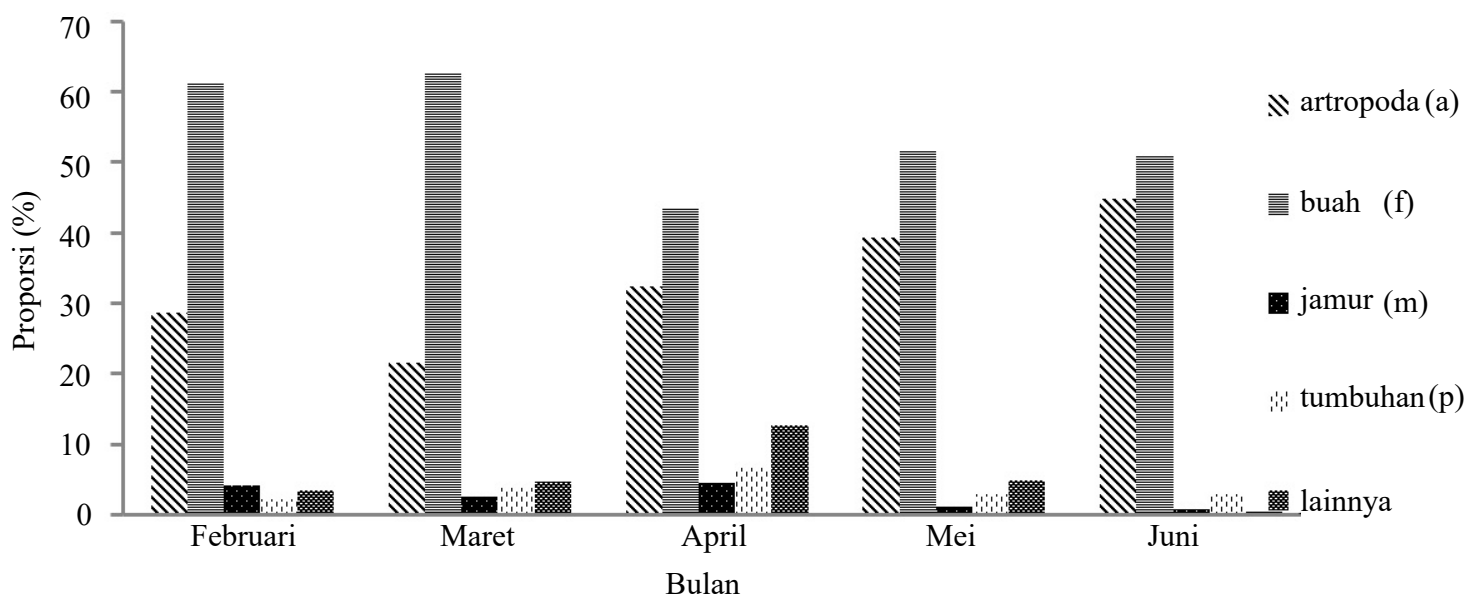

Gambar 7. Komposisi jenis pakan M. nigra setiap bulan (Februari-Juni 2014) 
waktu diurnal, proporsi perilaku harian tertinggi betina bunting yaitu makan. Hal tersebut menunjukkan bahwa pada masa kebuntingan, $M$. nigra membutuhkan masukan energi yang cukup besar untuk menunjang aktivitasnya sekaligus sebagai sumber nutrisi untuk perkembangan dan pertumbuhan janin di dalam kandungan.

Pola perilaku makan betina bunting seperti parabola, pagi dan petang hari memiliki proporsi yang relatif sama sedangkan pada tengah hari merupakan puncak dari perilaku makan M. nigra pada masa kebuntingan. Pola perilaku mencari makan menunjukkan sesuatu yang konstan pada tiga kategori waktu diurnal. Suatu organisme ketika mempunyai banyak sumberdaya makanan maka organisme tersebut cenderung sedikit untuk bergerak mencari makanan (Muhlenberg et al. 2004).

Pola perilaku lokomosi betina bunting berbentuk parabola terbalik, yaitu proporsi perilaku lokomosi terbesar pada pagi hari, kemudian menurun di tengah hari dan meningkat kembali di petang hari. Pola tersebut menunjukkan betina bunting aktif bergerak pada pagi dan petang hari, ketika turun dari pohon tidur dan beranjak naik menuju pohon tidur serta rendah di tengah hari, dengan tujuan mengalokasikan energi untuk makan, mencari makan, dan posisi (istirahat, tidur, dan tidak melakukan perilaku apapun). Proporsi dan pola perilaku posisi M. nigra pada masa kebuntingan relatif sama dari tiga kategori waktu diurnal. Ketika pagi hari dan petang hari, $M$. nigra bunting aktif melakukan lokomosi, dan sedikit melakukan posisi sedangkan saat tengah hari, $M$. nigra bunting lebih banyak melakukan perilaku posisi daripada lokomosi.

Perilaku Harian M. nigra Berdasarkan Perbedaan Mester Kebuntingan. Proporsi perilaku harian pada masa kebuntingan erat kaitannya dengan penggunaan dan ketersediaan energi di alam. Perilaku harian yang erat kaitannya pada masa kebuntingan yaitu perilaku makan. Menurut Silk dan Joan (1987) pada primata dalam masa kebuntingan akan memiliki proporsi perilaku makan yang selalu lebih besar diantara proporsi perilaku lainnya. Pola perilaku makan $M$. nigra pada 3 mester kebuntingan berbentuk seperti parabola pada mester 2 kebuntingan.

Perilaku lain yang erat kaitannya dengan pemilihan strategi saat kebuntingan yaitu perilaku lokomosi dan posisi. Pada tiga mester kebuntingan M. nigra, proporsi perilaku posisi selalu lebih besar daripada perilaku lokomosi. Pada saat kebuntingan, M. nigra akan memilih untuk menyimpan energi dengan cara beristirahat dibandingkan melakukan perilaku lokomosi. Selain itu ketika sumber pakan melimpah, maka perilaku lokomosi khususnya untuk mencari makan akan berkurang. Hal ini menyebabkan energi yang diperoleh akan bisa lebih optimal dimanfaatkan untuk memenuhi kebutuhan induk dan nutrisi untuk perkembangan dan pertumbuhan janin di dalam kandungan.

Perubahan Intensitas Warna di Sekitar Daerah Urogenital. $M$. nigra mengalami perubahan warna kulit pada daerah sekitar urogenitalnya. Perubahan warna yang jelas terjadi pada periode kebuntingan dan menjelang melahirkan. Hal tersebut dapat dijadikan sebagai bahan pendugaan kebuntingan dan prediksi waktu melahirkan. Ketika masa kebuntingan sudah sampai mester ketiga warna kulit disekitar daerah urogenital akan mulai berwarna merah sedikit gelap. Dua sampai tiga minggu sebelum melahirkan warna merah akan semakin gelap ungu. Ketika sudah sampai pada satu minggu menjelang melahirkan warna akan semakin ungu gelap. Intensitas warna akan kembali seperti sebelum bunting beberapa minggu setelah melahirkan yaitu berwarna merah muda (light pink). Perubahan intensitas warna ini erat kaitanya dengan perubahan hormonal terutama menjelang kelahiran yaitu meningkatnya hormon estrogen yang menyebabkan terjadinya vasodilatasi (pelebaran pembuluh darah).

Pada beberapa genus di primata, individu betina menampilkan perubahan warna yang cerah selama masa kebuntingan (Gerald et al. 2008). Pada $M$. mulatta, betina bunting menunjukkan perubahan warna wajah dari merah menjadi merah keunguunguan, hal tersebut merupakan strategi betina bunting memberikan sinyal peringatan kepada individu lain untuk mengurangi perilaku agonistik terhadap dirinya sehingga kebuntingan dapat terus dipertahankan (Gerald et al. 2008). Selain pada masa kebuntingan, perubahan warna kulit juga terjadi pada periode folikuler, ovulasi, dan luteal (Weinbauer et al. 2008). M. fascicularis menunjukkan perubahan warna kulit seksual di daerah perineal, dimana pada periode folikuler berwarna merah dan semakin merah pada periode ovulasi. Pada periode luteal kulit seksual di daerah perineal kembali menjadi merah muda.

Perbandingan Perilaku Harian M. nigra pada Periode Siklus, Bunting, dan Laktasi. Energi yang diperlukan oleh suatu organisme berbeda-beda pada tiap periode kehidupan satwa. Perilaku harian memiliki kaitan yang erat dengan ketersediaan energi dan pemakaian energi yang ada di alam. Pemakaian energi dipengaruhi oleh kondisi internal organisme tersebut. Ketersediaan energi, pemakaian energi dan kondisi internal organisme akhirnya akan mempengaruhi perilaku harian dari suatu organisme. Salah satu bentuk kondisi internal tersebut yaitu sebelum kebuntingan (siklus), saat kebuntingan, dan setelah melahirkan (laktasi).

Berdasarkan data yang didapatkan terlihat perbedaan proporsi perilaku harian yang diperlihatkan oleh 
monyet hitam sulawesi. Perbedaan proporsi perilaku harian yang terlihat dan berkaitan erat yaitu perilaku makan, lokomosi, dan posisi. Perilaku harian paling tinggi $M$. nigra betina baik pada periode siklus, bunting dan laktasi adalah perilaku makan. Hal tersebut sesuai dengan penelitian sebelumnya yang menyatakan bahwa M. nigra khususnya betina merupakan individu yang menghabiskan sebagian aktivitasnya untuk makan (O’Brien dan Kinnaird 1997; Giyarto 2010).

Pada masa kebuntingan, peningkatan berat tubuh pada individu diikuti dengan meningkatkan proporsi perilaku makan (27.03\%) dibandingkan ketika periode siklus (26.60\%). Menurut Terborgh (1983) dan O’Brien dan Kinnaird (1997), peningkatan berat tubuh pada suatu individu akan meningkatkan proporsi perilaku makan. Selain itu, meningkatnya perilaku makan merupakan strategi yang dilakukan oleh $M$. nigra untuk mencukupi kebutuhan energi saat masa kebuntingan sampai proses melahirkan. Tingginya proporsi perilaku makan pada masa sebelum kebuntingan (siklus) dan saat kebuntingan, tidak diikuti pada masa beberapa minggu setelah melahirkan (14.98\%), proporsi perilaku harian lebih besar digunakan untuk perilaku posisi.

Perilaku lain yang erat kaitannya dengan strategi tersebut yaitu lokomosi dan posisi. Proporsi perilaku lokomosi dan posisi periode siklus $(16.16 \%)$ dan (11.30\%), hal tersebut dikarenakan M. nigra betina pada masa siklus aktif bergerak mendekati jantan untuk melakukan presenting kepada jantan dan dilanjutkan dengan mating dari setiap jantan yang ada di dalam grup. Proporsi perilaku lokomosi mulai mengalami penurunan pada saat kebuntingan $(9.65 \%)$ dan semakin menurun pada saat setelah melahirkan (7.03\%). Menurunnya proporsi perilaku lokomosi, diikuti dengan peningkatan proporsi perilaku posisi saat kebuntingan (13.45\%) dan semakin meningkat beberapa minggu setelah melahirkan (26.12\%).

Seperti dikatakan oleh Silk dan Joan (1987), betina yang sedang bunting memiliki dua strategi untuk memenuhi kebutuhan energi. Strategi pertama yaitu dengan meningkatkan proporsi makan, strategi yang kedua yaitu dengan mengurangi penggunaan energi untuk bergerak. Adanya pola turun dan naik pada proporsi perilaku lokomosi dan posisi merupakan bentuk strategi yang dipilih untuk mengurangi pemakaian energi, terutama saat laktasi.

Inventarisasi Pakan M. nigra di Cagar Alam Tangkoko-Batuangus. Buah merupakan sumber pakan terbesar bagi M. nigra, karena pada dasarnya M. nigra merupakan hewan frugivor. Berdasarkan data yang diperoleh bagian yang dimakan dari buah adalah daging buah, serabut (Cocos nucifera), dan kulit luar buah (Mucuna albertisii, Terminalia catappa, dan Terminalia celebica). Dari jenis buah yang berhasil diinventarisasi, beberapa jenis diantaranya merupakan tumbuhan eksotis, yaitu Arenga pinnata, C. nucifera, Piper aduncum, dan Macaranga mappa (Sari 2013). Jenis pakan lain adalah tumbuhan seperti daun, daun muda, batang, batang muda, dan tunas, arthropods (seluruh tubuh dimakan), dan mushroom (bagian yang dimakan berupa tubuh buah).

Macaca nigra pada umumnya mengkonsumsi buah yang sudah matang, dan sesekali memakan buah yang belum matang. Menurut Lee (1997) terdapat 5 buah favorit $M$. nigra yaitu $D$. dao, Cananga odorata, Ficus spp, Eugenia spp, Canarium hirsutum. Berdasarkan pengamatan yang dilakukan buah yang sering dikonsumsi yaitu Morinda citrifolia, Morinda bracteata, P. aduncum, C. nucifera, D. dao, A. pinnata, Leea indica, dan M. albertisii. Jenis pakan tumbuhan selain buah yang sering dimakan yaitu Caryota mitis dan P. aduncum. Selain buah dan tumbuhan, inventarisasi pakan juga berhasil mencatat jenis pakan lain, yaitu artropoda dan jamur. Jenis pakan artropoda yang sering dikonsumsi yaitu semut (Anoplolepsis gracilipes dan Acropyga sp.) serta ulat yang berhasil diidentifikasi sampai tingkat famili (Geometridae). Jenis pakan mushroom yang berhasil dicatat dan diidentifikasi yaitu jamur Pleurotus sp., Russula sp., Amanitopsis sp., dan Termitomyces sp.

Proporsi dan Komposisi Jenis Pakan M. nigra. Proporsi jenis pakan terbesar betina bunting adalah buah (54\%). Pemilihan buah sebagai jenis pakan utama karena M. nigra merupakan jenis hewan frugivor yang membutuhkan glukosa sebagai sumber energi utama. Artropoda (34\%) merupakan sumber pakan terbesar kedua selama masa kebuntingan, kemudian diikuti tumbuhan dan jamur. Penggunaan artropoda sebagai sumber pakan karena untuk memenuhi kebutuhan protein yang tidak didapatkan dari buah (Giyarto 2010). Konsumsi jenis pakan lainnya seperti tumbuhan selama kebuntingan dilakukan untuk memenuhi kebutuhan serat yang tidak didapatkan dari buah atau artropoda.

Komposisi jenis pakan M. nigra berbeda setiap bulannya. Perbedaan tersebut dapat dikaitkan dengan daerah jelajah dari M. nigra setiap harinya. Daerah jelajah M. nigra berupa hutan pantai (21.25 pohon/ ha), hutan dataran rendah sekunder (12.5 pohon/ha), hutan dataran rendah primer (19.17 pohon/ha), hutan dataran rendah peralihan (21.67 pohon/ha), dan hutan pasca terbakar (7.5 pohon/ ha) (Hakim 2010). Daerah jelajah erat kaitannya dengan perilaku makan. Monyet harus mencari makan untuk dapat bertahan hidup, hal ini berhubungan langsung dengan daerah jelajah sebagai respon dari distribusi pakan untuk setiap habitat (Robinson 1986; O’Brien dan Kinnaird 1997).

Menurut O'Brien dan Kinnaird (1997) buah menjadi jenis pakan yang paling banyak dimakan karena untuk setiap daerah jelajah memiliki kerapatan yang cukup besar. Nilai kerapatan tersebut menjadikan 
kelimpahan buah yang cukup besar sebagai sumber utama bagi M. nigra. Daerah jelajah M. nigra seperti hutan pasca terbakar memiliki tumbuhan tingkat semai yang sangat besar. Tumbuhan tingkat semai memiliki peranan penting karena menjadi sumber pakan lain selain buah, karena selain bisa langsung dimakan bagiannya selain buah, juga banyak artropoda yang tinggal di dalam tumbuhan tersebut (Hakim 2010).

Pengaruh Aspek Iklim Terhadap Komposisi Pakan M. nigra. Macaca merupakan genus yang lebih bergantung kepada siklus fenologi dari tumbuhan pakan spesifik dibandingkan dengan pengaruh aspek iklim seperti ada atau tidak adanya hujan (Chapman 1988; Sari 2013). Menurut Sari (2013) di CA Tangkoko-Batuangus, iklim (curah hujan dan suhu) memiliki pengaruh yang kecil terhadap hasil buah, contohnya Ficus spp. Selama 5 bulan pengamatan, bervariasinya jenis dan jumlah buah pakan yang ditemukan membuat $M$. nigra bebas memilih buah yang akan dimakannya. Ketika satu jenis buah sudah habis, $M$. nigra akan memanfaatkan jenis buah yang lain, seperti $C$. nucifera dan $P$. aduncum yang sangat berlimpah di CA Tangkoko-Batuangus.

Ketersediaan artropoda di CA Tangkoko-Batuangus juga sangat melimpah. Pemilihan pakan artropoda terlihat meningkat ketika curah hujan mulai rendah dan suhu mulai meningkat (bulan Mei sampai dengan Juni). Hal tersebut dikarenakan pada bulan-bulan tersebut $M$. nigra $\mathrm{R} 1$ memilih daerah jelajah di hutan pasca terbakar, hutan pantai, dan hutan sekunder yang memiliki kelimpahan buah tidak sebesar di hutan primer. Selain itu, pemilihan artropoda sebagai jenis pakan terbesar kedua merupakan pilihan terbaik untuk memenuhi nutrisi selain dari buah terutama selama kebuntingan.

\section{KESIMPULAN DAN SARAN}

Simpulan. Proporsi perilaku harian tertinggi betina bunting yaitu makan. Pola perilaku makan betina bunting pada pagi dan petang hari memiliki proporsi yang relatif sama sedangkan pada tengah hari merupakan puncak dari perilaku makan M. nigra pada masa kebuntingan. Pola perilaku lokomosi betina bunting terbesar pada pagi hari kemudian menurun di tengah hari dan meningkat kembali di petang hari. Proporsi dan pola perilaku posisi $M$. nigra pada masa kebuntingan relatif sama dari tiga kategori waktu diurnal. Perilaku harian yang erat kaitannya pada masa kebuntingan yaitu perilaku makan, lokomosi, dan posisi. Pola perilaku makan M. nigra pada tiga mester kebuntingan memiliki perbedaan pada setiap mesternya. Aspek iklim mempengaruhi proporsi dan komposisi pakan M. nigra.

Saran. Penulis menyarankan untuk pihak yang ingin melanjutkan penelitian ini sebaiknya mengalokasikan waktu penelitian yang lebih lama. Waktu yang lebih lama untuk penelitian yang bersifat eksploratif, khususnya perilaku harian, dapat menghasilkan hasil yang lebih baik.

\section{UCAPAN TERIMA KASIH}

Penulis mengucapkan terimakasih kepada Dr Antje Engelhardt sebagai Direktur Macaca Nigra Project (MNP) yang telah memberikan izin dan fasilitas selama penelitian ini berlangsung. Penulis juga mengucapkan terima kasih kepada kepala Balai Konservasi dan Sumberdaya Alam (BKSDA) Sulawesi Utara atas pemberian izin masuk ke kawasan konservasi Tangkoko.

\section{DAFTAR PUSTAKA}

Asteria, Yuriestia A, Raharjo L, Sjahfirdi L, Adil E, Maheswari H, Astuti P. 2008. Aktivitas Harian Yaki (Macaca nigra) di Penangkaran Selama Periode Estrus dan Anestrus. Proceeding $2^{\text {nd }}$ Seminar Nasional Biodiversitas, Surabaya, Indonesia.

Chapman C. 1988. Patterns of foraging and range use by three species of neotropical primates. Primates 29:177-194.

Fooden J. 1969. Taxonomy and Evaluation of the Monkeys of Celebes (Primates: Cercopithecidae). Basel: S Karger.

Gerald MS, Waitt C, Little AC. 2008. Pregnancy coloration in macaques may act as a warning signal to reduce antagonism by conspecifics. Behavioral Processes 80:7-11.

Gholib. 2011. Non-invasive hormone monitoring: faecal androgen and glucocorticoid in male crested macaques (Macaca nigra) in relation to seasonal and social factors [Tesis]. Bogor: Institut Pertanian Bogor.

Giyarto. 2010. Penggunaan home range dan aktivitas harian monyet hitam sulawesi (Macaca nigra Desmarest, 1822) di Cagar Alam Tangkoko-Batuangus, Sulawesi Utara [Skripsi]. Yogyakarta: Universitas Gadjah Mada.

Higham JP, Heistermann M, Saggau C, Agil M, PerwitasariFarajallah D, Engelhardt A. 2012. Sexual signalling in female crested macaques and the evolution of primate fertility signals. BMC Evol Biol 12:89-95.

Hakim SS. 2010. Karakteristik habitat dan populasi monyet hitam sulawesi (Macaca nigra Desmarest, 1822) pada beberapa tipe habitat di Cagar Alam Tangkoko, Sulawesi Utara [Skripsi]. Bogor: Institut Pertanian Bogor.

[IUCN] International Union for Conservation of Nature. 2009. IUCN Red List of Threatened Species, Crested Macaques (Macaca nigra). Tersedia pada: http://www.iucnredlist. org [Data akses: 20 September 2013]

Lee RJ. 1997. The Impact of Hunting and Habitat Disturbance on the Population Dynamics and Behavioral Ecology of the Crested Black Macaque (Macaca nigra) [Disertasi]. Oregon (US): University of Oregon.

Martin P, Bateson P. 1993. Measuring Behaviour: an Introductory Guide. $2^{\text {nd }}$ ed. Cambridge: Cambridge University Pr.

Melfi V. 2010. Selamatkan Yaki! Conservation of Sulawesi Crested Black Macaques Macaca nigra. In S. Gursky and J. Supriatna (Eds.), Indonesian Primates. Tersedia pada: http://www.springerlink.com [Data akses: 10 Maret 2014]

Muhlenberg M, Pombo AR, Waltert M, Mansjoer SS, Mardiastuti A. 2004. Home Range, Diet, and Behaviour of the Tonkean Macaque (Macaca Tonkeana) in Lore Lindu National Park, Sulawesi. In G. Gerold, M. Fremerey, and E. Guhardja (Eds.), Land use, nature conservation and the stability of rainforest margins in southeast asia. Heidelberg: Springer. p. $313-325$ 
O'Brien TG, Kinnaird MF. 1997. Behavior, diet, and movements of the Sulawesi crested black macaque (Macaca nigra) Int J Primatol 18:321-351.

Palacios JFG, Engelhardt A, Agil M, Hodges JK, Bogia R, Waltert M. 2012. Status of, and conservation recommendations for, the Critically Endangered crested black macaque Macaca nigra in Tangkoko, Indonesia. Oryx 46:290-297.

Riley EP. 2010. The endemic seven: Four decades of research on the Sulawesi macaques. Evolutionary Antrophology 19:22-36.

Robinson JG. 1986. Seasonal variation in use of time and space by the wedge capped capuchin monkey, Cebus olivaceus: Implications for foraging theory. Smithson Contrib Zool 431:1-60.

Rosenbaum B, O’brien TG, Kinnaird M, Supriatna J. 1998. Population densities of Sulawesi crested black macaques (Macaca nigra) on Bacan and Sulawesi: Effects of habitat disturbance and hunting. Am J Primatol 44:89-106.
Sari IR. 2013. Anthropogenic effects on habitat use, activity budget, and energy balance in Macaca nigra at Tangkoko Nature Reserve, North Sulawesi, Indonesia [Tesis]. Germany: Georg-August University Göttingen.

Silk, Joan B. 1987. Activities and feeding behaviour of free-ranging pregnant baboons. International Journal of Primatology 8:593-613.

Sugardjito J et al. 1989. Population survey of macaques in northern Sulawesi. American Journal of Primatology 18: 285-301.

Terborgh J. 1983. Five New World Primates: A Study in Comparative Ecology. Princenton: Princeton University Pr.

Weinbauer GF, Niehoff M, Niehaus M, Srivastav S,Fuchs A, Van Esch E, Mark Cline J. 2008. Physiology and Endrocinology of the Ovarian Cycle in Macaques. Toxicologic Pathology 36:7-23.

Whitten T. 1987. The ecology of Sulawesi. Yogyakarta: UGM Pr. 